\title{
DIURNAL BITING ACTIVITY OF FOUR ZOOPHILIC SPECIES OF SIMULIUM IN AN AREA ENDEMIC FOR HUMAN ONCHOCERCIASIS IN GUATEMALA*1
}

\author{
Yoshinisa Hashiguchi*2, Isao Tada*3, Otto Flores C.*4 \\ and Hiroyuki TakaOKa*5 \\ Received for publication July 311982
}

\begin{abstract}
Summary: The biting activity of four zoophilic species of Simulium was examined in an area endemic for human onchocerciasis in Guatemala, using bovine baits. The surveys were performed at three sites within San Vicente Pacaya county (SVP) from daylight until nightfall of two days in January 1979. A total of 8,203 blackflies were collected from the baits throughout the collections. Of these flies, 6,531 (79.6\%) were Simulium metallicum s. 1.; 977 (11.9\%), S. pulverulentum; 654 (8.0\%), S. callidum; and $41(0.5 \%)$, S. rubicundulum. Biting activity of $S$. metallicum s. 1. peaked between 0800 to 0900 hours and a second peak was noted between 1500 to 1600 hours. S. callidum also exhibited two peaks, one in the morning and the other, more pronounced, in the late afternoon, immediately before the night-fall. The remaining two species, $S$. pulverulentum and $S$. rubicundulum were mainly mid-morning attackers of cattle. Thus, the rate of species composition was presumed to differ within a day.
\end{abstract}

\section{INTRODUCTION}

With regard to human onchocerciasis in Guatemala, amny entomological studies have been carried out in connection with the transmission of the disease. The data reported hitherto incriminated Simulium ochraceum as the most important vector, followed by $S$. metallicum s. 1. and S. callidum (Dalmat, 1955; De Leon \& Duke, 1966; Garms, 1975; Collins, 1979). The first species is markedly anthropophilic, while the second and third are markedly zoophilic in their blood feeding behaviour (Dalmat, 1955; Wilton \& Collins, 1978). Recently, Collins et al. (1981) studied on the diurnal patterns of biting activities of these species including $S$. downsi, using human baits. With animal baits, on the other hand, little has been investigated about the biting activity of Guatemalan blackflies, Simulium spp. Such a study will give an information for a better understanding of the vector biology in the transmission of human onchocerciasis and/or bovine and equine onchocerciasis. Because the animals with onchocerciasis were commonly found in the areas endemic for human onchocerciasis

*1 This study was supported by the Ministry of Public Health, Republic of Guatemala, and by the Japan International Cooperation Agency (JICA). (ORCOP No. 63) *2 Department of Parasitology, Kochi Medical School, Nankoku City, Kochi, 781-51, Japan *3 Department of Parasitic Diseases, Kumamoto University School of Medicine, Kumamoto, 860, Japan *4 Servicio Nacionál de Erradicación de la Malaria, Ministerio de Salud Publica A. S., Guatemala, Guatemala, C. A.

*5 Division of Medical Zoology, Medical College of Oita, P. O. Box 37, Oita, 870-91, Japan 
in Guatemala (Hashiguchi et al., 1981). The present paper deals with the results of surveys on the diurnal activity and species composition in the cattle-biting of $S$. metallicum s. 1., S. callidum, S. pulverulentum and S. rubicundulum.

\section{Materials ANd Methods}

Fly collections were performed at three sites, Finca San José Guachipilín, Finca Tullio and Finca Terranova, within San Vicente Pacaya (SVP), Department of Escuintla, Guatemala. SVP is the pilot area since June 1976, under the Onchocerciasis Control Project established by the Guatemalan and the Japanese Governments. The present study sites, about $650 \mathrm{~m}$ to $700 \mathrm{~m}$ above sea level, stituated on the Pacific slopes of the Sierra Madre. All the blackfly collections were made on three cows at the respective sites; two collecting men and one animal bait were arranged in every collection. The two men captured the flies which were biting on the animal bait, using an aspirator. The collections were carried out from daylight until night-fall of the two consecutive days in January 1979. The blackflies captured were kept in sample tubes, separating them with hour-intervals, respectively; thereafter they were killed with $10 \%$ formalin. After taking the samples to the laboratory, the numbers and species compositions of the flies were assessed in each hour-interval.

\section{RESUlts}

Of 8,203 blackflies collected, 6,531 (79.6\%) were S. metallicum s. 1.; 977 (11.9\%), S. pulverulentum; $654(8.0 \%)$, S. callidum; and 41 (0.5\%), S. rubicundulum in the present surveys. The result indicates that the first species is the most dominant among the flies engorging on the animal in the area (SVP).

In Fig. 1, the numbers of blackflies captured during two consecutive days at the three sites were summed up, and the biting densities were expressed as percentages of the flies in hour-interval, among the total collections of the respective species throughout the days. Biting activity of S. metallicum s. 1. reached a peak between 0800 to 0900 hours, and the second peak was found between 1500 to 1600 hours. S. callidum, on the other hand, exhibited the first distinct peak of the biting activity in the period from 1700 to 1800 hours, followed by the second from 0800 to 0900 hours. In $S$. pulverulentum only one remarkable peak of the activity was noted during the hours from 0900 to 1000 , while $S$. rubicundulum indicated two peaks, one, more distinct, in the early morning (0800 to 0900 hours), the other in the early afternoon (1300 to 1400 hours).

In Fig. 2, the species composition was expressed as percentages of each fly species, among the total numbers of the four species captured in each hour-interval throughout the collections. S. metallicum s. l. was the dominant cattle-biting species in the survey area (SVP) from daylight until night-fall, though there were two troughs, one in the late morning and the other in the late afternoon. In connection with these troughs, $S$. pulverulentum showed a relatively high rate of the composition in the species during the hours from 1000 to 1100 , whereas $S$. callidum composition increased steadily from 1500-1600 and peaked at the hours, 1700-1800, immediately before the night-fall. The remaining species, $S$. rubicundulum, was constantly low in the composition through- 


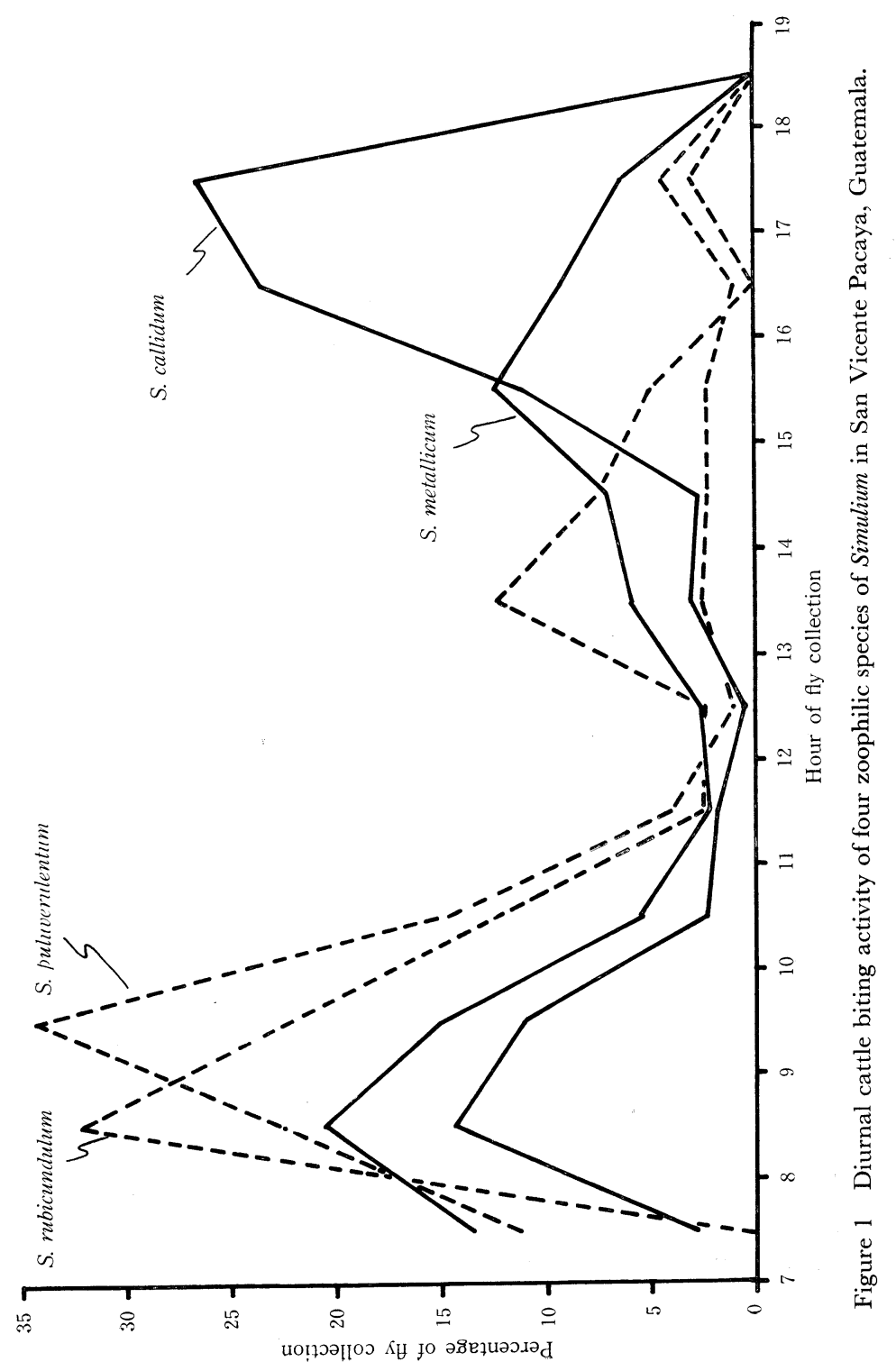




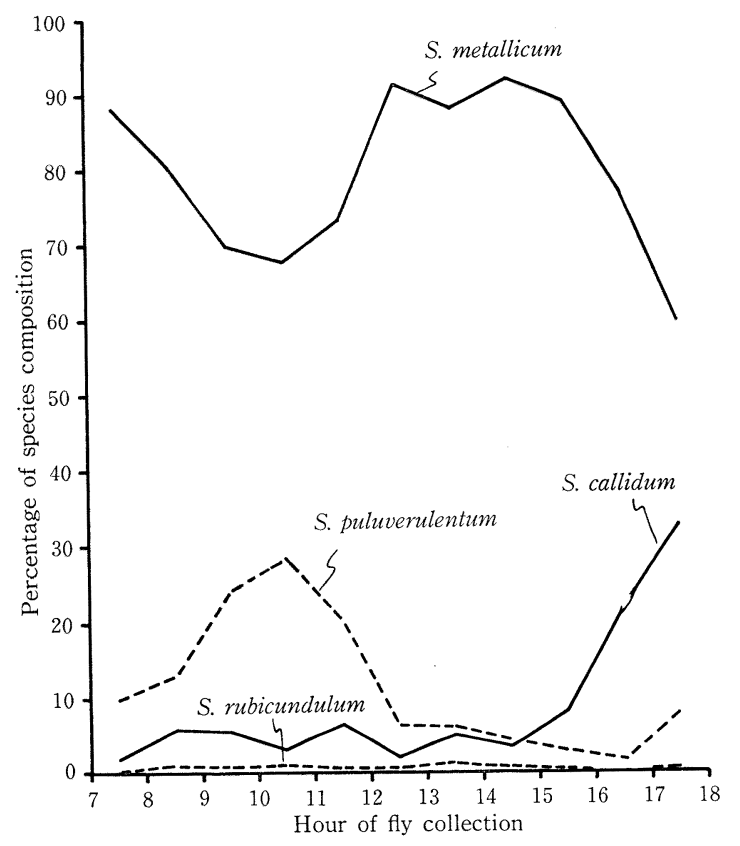

Figure 2 Diurnal species compositions of cattle biting flies of four zoophilic species of Simulium in San Vicente Pacaya, Guatemala.

out the day, only 41 individuals being collected during the fly catching.

\section{Discussion}

Among the present zoophilic blackfly species, both $S$. metallicum s. 1. and $S$. callidum are known to bite man, and they are considered to be potential vectors of human onchocerciasis. Apparently, these blackflies are markedly zoophilic in their blood feeding activities. It would be, therefore, necessary to investigate the biting activity of the flies using animal baits, in terms of an understanding of the vector biology.

When the present fly collections were made on the bovine baits, S. metallicum s. 1. and S. callidum, respectively, showed two distinct peaks of biting activities in the day, one in the morning and the other in the afternoon. According to Collins et al. (1980) who worked with human baits, the man biting activity of S. callidum peaked at 1500-1700 hours, and S. metallicum s. 1. was also somewhat more active in the afternoon, particularly between 1400 and 1700 hours at Finca Los Tarrales in Guatemala; their study area has a similar elevation with the present study sites. These peak biting activities of the both species are slightly different from those found in the present surveys. The discrepancy may be caused by the host difference between human and bovine baits. Thus, it is assumed that there will be some difference in the host preference of the flies, according to the time of the day.

Most of $S$. pulverulentum and $S$. rubicundulum, were found to have a distinct peak 
activity mainly in the mid-morning. This indicates that both of them are morning attackers of the animals in SVP. On the other hand, these two species were found to be hardly attracted by men (fly collectors), suggesting that they are solely zoophilic. The present study area (SVP) being a highly endemic zone of bovine and equine onchocerciasis with $O$. gutturosa and $O$. cervicalis, respectively (Hashiguchi et al., 1981), it seems likely that these species including $S$. metallicum s. 1 . and $S$. callidum are involved in the transmission of non-human onchocerciasis though the vector of the disease remains still to be determined in Guatemala. In addition, the area is also known as the endemic focus of human onchocerciasis with various intensities of the infections in the residents of villages and plantations within SVP (Tada et al., 1979). In such an area, the possible infection of $S$. metallicum $\mathrm{s}$. I. and $S$. callidum with the larvae of bovine or equine Onchocerca should be taken into consideration, especially in the evaluation of the vector control of the human disease.

In species composition of the flies, there were only four species which landed on the bovine baits for blood feeding. Although $S$. ochraceum, the principal vector of human onchocerciasis in Guatemala, was commonly found during the fly catching in the study sites, none of this species was attracted by the bovine baits. In SVP, S. metallicum s. 1. was the dominant bovine attacker in each hour-interval throughout the days. A relatively high composition of $S$. pulverulentum was noted in the morning, whereas $S$. callidum composition increased in the late afternoon.

Further detailed examinations on the biting activity of these zoophilic and/or anthropophilic species should be made in future, in relation to their ovipositions and host seeking behaviours, as mentioned by Garms (1975) and Collins et al. (1981) on the anthropophilic species, $S$. ochraceum.

\section{Acknowledgements}

Sincere gratitude is extended to Drs. J. J. Castillo O., H. A. Godoy B., H. Figueroa M., H. Takahashi, F. J. Aguilar, S. Hayashi for their encouragement throughout the present study. Thanks are also due to the owners of three Fincas San José Guachipilín, Tullio and Terranova for their supports during the field phase of this study. The present work was carried out by the helpful assistance of our collaborators in Servicio Nacional de Erradicación de la Malaria, Guatemala. We wish to show our sincere thanks to all of those who participated in the field examination.

\section{REFERENCES}

1) Collins, R. C. (1979): Onchocerciasis transmission potentials of four species of Guatemalan Simuliidae, Am. J. Trop. Med. Hyg., 28, 72-75

2) Collins, R. C., Merino, M. E. \& Cupp, E. W. (1981): Seasonal trends and diurnal patterns of man-biting activity of four species of Guatemalan black flies (Simuliidae), Am. J. Trop. Med. Hyg. 30, 728-733

3) Dalmat, H. (1955): The black flies of Guatemala and their roles as vectors of onchocerciasis, Smithson Misc. Coll., Vol. 125, No. 1., 425 pp 
4) De Leon, J. R. \& Duke, B. O. L. (1966): Experimental studies on the transmission of Guatemalan and West African strains of Onchocerca volvulus by Simulium ochraceum, S. metallicum and S. callidum, Trans. Roy. Soc. Trop. Med. Hyg., 60, 735-752

5) Garms, R. (1975): Observations on filarial infections and parous rates of anthropophilic black flies in Guatemala, with reference to the transmission of Onchocerca volvulus, Tropenmed. Parasit., 26, 169-182

6) Hashiguchi, Y., Tada, I., Ochoa, J. O. A., Recinos, C. M. M. \& Molina, P. A. (1981): Bovine and equine onchocerciasis in Guatemala, especially in San Vicente Pacaya, J. Parasitol., 67, 286-287

7) Tada, I., Aoki, Y., Rimola, C. E., Ikeda, T., Matsuo, K., Ochoa, J. O. A., Recinos, C. M. M., Sato, S., Godoy, B. H. A., Castillo, O. J.J. \& Takahashi, H. (1979): Onchocerciasis in San Vicente Pacaya, Guatemala, Am. J. Trop. Med. Hyg., 28, 67-71

8) Wilton, D. P. \& Collins, R. C. (1978): An entomologic and parasitologic survey for onchocerciasis in western El Salvador, Am. J. Trop. Med. Hyg., 27, 499-502

$$
\begin{gathered}
\text { グァテマラのオンコセルカ症流行地における } 4 \text { 種のブュの } \\
\text { 牛に対する吸血活動の日周性について }
\end{gathered}
$$

橋口義久 $* 1 \cdot$ 多田 功*2 $\cdot$ Otto Flores C. ${ }^{* 3} \cdot$ 高岡宏行 $* 4$

\footnotetext{
グァテマラのオンコセルカ症流行地の一つである San Vicente Pacaya 郡の 3 地点に㧍いて牛を㧢 としてブュの吸血活動について調査した。調査は連続 2 日間終日行い, 4 種のブュを含む合計 8,203 個体の雌成虫が採集された。最優先種は S. metallicum s. 1. (79.6\%) で，以下 S. pulverulentum (11.9 $\%)$, S. callidum (8.0\%) および S. rubicumdulum (0.5\%) であった。S. metallicum s. 1. の吸血活動に は, 午前中の 8-9 時と午後の 3-4 時に各々第 1 および第 2 の山を示す二峰性の日周期が認められ た。また S. callidum む同様の二峰性を示したが，大きな山は日没直前にみられた。一方，他の 2 種 の日周活動はいずれも一峰性で，その山は午前中にみられた。このように，各ブユ種別に吸血活動の 日周パターンが異なることを反映して相対的種構成比は一日のうちの時刻によって異なる傾向を示し た。
}

*1 高知医科大学環境保健医学講座寄生虫学教室 $\quad * 2$ 熊本大学医学部寄生虫病学教室 *3グァ テマラ共和国厚生省マラリア防圧研究所 